Meta

Journal des traducteurs

Translators' Journal

\title{
Is the Muse Bilingual?
}

\section{G. V. Downes}

Volume 14, numéro 4, décembre 1969

URI : https://id.erudit.org/iderudit/002584ar

DOI : https://doi.org/10.7202/002584ar

Aller au sommaire du numéro

Éditeur(s)

Les Presses de l'Université de Montréal

ISSN

0026-0452 (imprimé)

1492-1421 (numérique)

Découvrir la revue

Citer cet article

Downes, G. V. (1969). Is the Muse Bilingual? Meta, 14(4), 195-199.

https://doi.org/10.7202/002584ar

Ce document est protégé par la loi sur le droit d'auteur. L’utilisation des services d'Érudit (y compris la reproduction) est assujettie à sa politique d'utilisation que vous pouvez consulter en ligne.

https://apropos.erudit.org/fr/usagers/politique-dutilisation/
Cet article est diffusé et préservé par Érudit.

Érudit est un consortium interuniversitaire sans but lucratif composé de l'Université de Montréal, l'Université Laval et l'Université du Québec à Montréal. Il a pour mission la promotion et la valorisation de la recherche. https://www.erudit.org/fr/ 


\section{is \\ the}

\section{muse bilingual}

Both the creation and translation of poetry involve fundamentally the same process, a mental act, an act of sympathetic magic. In creation, the poet is exorcising and controlling his experience by defining it in an essentially verbal framework. This may be a set harmonic form or a freer one which he has chosen himself, according to the demands of his material, but in both cases the aural quality of the work, which appeals to the unconscious ear, is as important as the subtle network of interlocking associations which are created by the language.

Given these two factors, the sound and the sense, how can a poem really be shifted from one set of intellectual and harmonic values to another? Should it, indeed, be translated? I used to answer « No » to both these questions because the very act of translation in poetry implies a point of view with which I have never agreed, namely, that a work of art exists apart from the medium in which it lives and moves and has its being. If you express an English sonnet in English prose, you may have written something, but your prose is not the sonnet. If you turn Baudelaire's la Charogne into English, you have destroyed the sound values of the original version without (usually) re-creating others as a substitute. The medium, in this and countless other successful poems, really is the message. But it is clear that, although such a point of view may be esthetically justifiable, other considerations are more important, and indeed always have been in the history of literature. In Canada today, for example, the need of translations is obvious; the bilingual writer finds himself working in a society which is becoming more and more aware of the rôle the translator can play in interpreting various parts of the national dialogue.

But in order to interpret the magic of poetry he must become a magician in the same sense that the author was. That is, he must attempt, by an act which is fundamentally intuitive, to enter into the poetic universe created by the poem. By its mere existence as an art form, set off from the chaos of reality, the poem 
operates within a framework indicated by the words on the page. The faithful translator attempts to live within this universe - his only clues to it being words and then to re-create as carefully as possible the «meaning » and the atmosphere of the original poem, even though he is using a different set of associations and a different set of sound values. I do not intend to imply that every English word has associations different from those of its French equivalent. But in poetry, which is above all an art of precision, there are enough nuances involved in the language used by any successful poet to create one obstacle after another for the translator. Sometimes they all occur at once - syntax, vocabulary, images.

In my own experience, I have found that there are three styles of translation, although the frontiers between them are a little blurred. The first, for want of a better word, can be called the expressionistic, and if the translator is a working poet in his own language this is probably the most direct way he can take to produce an effect which is analogous to that of the original poem. He does not attempt to follow the French poet's syntax. Using the data of the images, language, and what one might call the "organic $»$ flow of the poem he writes a fresh poem in English in the way which comes to him most naturally, spelling out the truths which he has understood. This is not an easy method, since each poem creates its own problems which must be constantly met, constantly solved. It does, however, have the merit of sounding authentic in the second language. The dangers of this method are that the poet's original intention may get diluted or even lost if the translator becomes enchanted by the sound of his own voice; only a strong professional conscience can save him and the poet from this peril.

The second type of translation is the exact opposite of poetic free-wheeling. It consis's of a scrupulous respect for the syntax and language of the original, with the least possible disturbance of the relations between them consonant with the grammatical laws of the second language. At its best, with suitable material and in the right hands, this method produces translations such as the brilliant versions made by F.R. Scott of Anne Hébert's le Tombeau des rois, and other poems by the same author. As its worst, it lapses into prosiness, banality, awkwardness; there are no half-felt underlying natural rhythms; the poetry disappears as the dictionary takes over.

Used properly, this technique is probably the fairest to the poet. But unfortunately only a small proportion of poems seem to lend themselves to this type of interpretation. Close though English and French are in some ways, they are very different in others, and it is in dealing with the differences that the translator who wishes to be honest with the poet and his readers runs into the eternal problems of choice. What shall he do ? Remain faithful to the text and lose a certain poetic quality? Add a dash of his own invention in order to interpret the spirit rather than the letter of the text? Somewhat hesitantly, I have come to the conclusion that the only attitude to take is to say «free-wheeling if necessary, but not necessarily free-wheeling ». It seems better to keep the tone of the translation an even one within a given framework than to break it by the inclusion of an awkward phrase or an impossible word. So my third type of translation sets as its ideal the 
literal poetic, but is ready to sacrifice literal exactness under some circumstances. For instance, when Paul-Marie Lapointe writes :

\section{peu d'oiseaux sont blancs outre les colombes}

Sinon d'avoir vécu l'hiver ${ }^{1}$

what can one do with that phrase in English except avoid it ?

The French mind moves easily in the abstract. English, on the other hand, is very uneasy in the presence of abstractions, for to the English sensibility what is abstract is vague, rather than a clearly defined mathematical counter of thought. This habit is so ingrained in English speech that university students continually use the two words in conjunction with each other, as synonyms, « abstract and vague ».

The translator therefore, when he comes upon an abstract noun in French, must be aware that the word will lose half its evocative power if he simply gives it an English equivalent. In Yves Préfontaine's poem Dureté ${ }^{2}$, the noun is not only used as a title but also as a kind of leitmotiv introducing a series of strongly felt statements. And yet, if one tries to use « Hardness », or «Harshness » as the title and repeats it, the effect is not carried over into the second language. In this case, although not in all, there is also the difference between the strong French suffix -té, and the more weakly stressed English -ness. After experimenting with expressions such as : "Be harsh», «let us be hard», «we must be hard», I finally chose to pull a concrete noun out of the first line and combined it with the adjectival form dur; this provided : «The Harsh Country» as a title, and enabled me to repeat the adjective «harsh » in order to introduce the poet's statements without overloading the poem with unnecessary extra words.

Sometimes an English word which has very strong evocative force can be exploited to good effect. For instance, Rina Lasnier's l'Épouvantail ${ }^{3}$ opens with an abstraction "Flottement mou de la guenille». This is impossible to translate literarily because of the immediate loss of poetic power described in the previous paragraph, but the title in English «Scarecrow 》 carries great impact, possibly because of its strong Anglo-Saxon consonants, possibly because of the accumulated weight of association. So «Scarecrow» became the first word in the translation, while the line itself was placed further on (this poem was being done by the freewheeling method) and turned into « rags that softly stir».

Another stumbling block occurs with various forms of negation; it is perhaps natural that poets, who are so conscious of time and eternity, should use ne... plus. Parallel to ne... pas, ne... plus is a perfectly easy expression to use in French, capable of carrying an expanded meaning by additions such as rien and jamais. It has also a certain musical value, being a light and pleasant sound. But carried over in English, this expression immediately presents problems. The equivalent phrases « not... any more » or even « does not... any more » immediately load the line with a heavier weight of syllables than in the French; music flies out of the

1. Paul-Marie Lapointe, Pour les âmes, Montréal, Editions de l'Hexagone, 1964, p. 50.

2. Yves Préfontaine, Pays sans parole, Montréal, Editions de l'Hexagone, 1967, p. 47.

3. Rina Lasnier, Mémoire sans jours, Montréal, Les Editions de l'Atelier, 1960, p. 57. 
window. There is, of course, the shorter phrase «no longer » which can sometimes be used if it suits the rhythm of the translation; however, this phrase carries with it, to my ear, a few trailing clouds of romanticism and it may evoke a totally different atmosphere from the one created by the French poet. It is effective in poems where, in English, a poet might naturally use it, such as Anne Hébert's Petit désespoir, where, looking at the river she says in conclusion :

Mon cour est rompu

L'instant ne le porte plus ${ }^{4}$.

Translation :

The stream no longer bears

My tired heart

Plus can be even more awkward in another context. André Major writes «Et ta main est une comète/ qui m'éclaire plus qu'elle ne m'habite ${ }^{5} »$. Whatever one does with éclaire and habite, the bridge expression is clumsy in English, with the added problem of elle to be solved at the same time.

The relative pronouns ce qui, celui qui, and ceux qui present a different type of problem to the translator. It is true that English uses the first quite freely (Stephen Spender says : «What is important is never to forget 》) but the personal forms « he who» comes less easily to modern lips, and seems indeed to have faded as part of idiomatic speech. As a writer rather than a linguist, I do not pretend to have studied this phenomenon, if indeed it really exists, but I know that when Rina Lasnier writes as a first line,

Ceux-là qui n'ont pu attendre l'ancrage ${ }^{6}$

I cannot make anything but a weak start in English by using the equivalent, even strengthened by $-l \grave{a}{ }^{\top}$.

A similar example occurs in Alain Grandbois' Ce qui reste, where the title phrase becomes part of the first line ${ }^{8}$. It would be a very insensitive translator indeed who would destroy the music of "Ce qui reste de la nuit» by saying simply "What remains of [the] night 》 or worse « That which is left of night », a succession of heavy syllables that do not carry the rhythm of Grandbois' poem at ali.

A more subtle obstacle in the transference of feeling from one language to another is the whole question of the tone of the poem. What I am thinking of in particular is the atmosphere invoked by the choice of words or expressions which are characteristic of certain periods in the history of the language and which, therefore, must be handled with care when used in translation. The late Dr. G.G. Sedgewick of the University of British Columbia once made an interesting version in English, privately printed, of le Cimetière marin. The translation is an admirable one in many respects but for the fact that the available English vocabulary con-

4. Anne Hébert, Poèmes, Paris, Editions du Seuil, 1960, p. 23.

5. André Major, Quel feuillage, paru dans Poésie du Québec (éd. Alain Bosquet), Paris, Seghers, et Montréal, H.M.H., 1966, p. 270.

6. Rina Lasnier, op. cit., p. 80.

7. However, I notice that one of my own poems begins with "This one, diving for pearls". The subject should be investigated further.

8. Alain Grandbois, l'Etoile pourpre, Montréal, Editions de l'Hexagone, 1957, p. 67. 
nected with cemeteries is so Elizabethan or Jacobean in its connotations - graves, worms, epitaphs. Valéry's classical Mediterranean light is darkened by a shadow appropriate to Hamlet. It is of course immensely difficult, because of the deep influence of both Shakespeare and the Bible on English speech to avoid echoes of this kind.

One word which is impossible to translate from French to English in poetry is the word poitrine, whose physical equivalents «chest » or «breast», except in medecine, are completely out-dated as part of our working vocabulary. They are not only out-dated; their use has become so associated with the language of the Victorian novel that they merely inspire laughter, as in the cliche " his manly breast ». Occasionally the word « heart» may act as a reasonable substitute, but the translator here is up against a situation about which he can do nothing at all.

Perhaps I might conclude this discussion by saying that, in my own experience, the problems of the translator are a mirror-image of the problems of the poet in the original language. And of course the better the original poem, the more difficult the successful translation. As John Glassco has pointed out ${ }^{9}$, the need for accurate renderings in English of French poems is urgent. One hopes that an understanding of the difficulties involved will serve as a spur and a challenge to the would-be translator, rather than a deterrent.

G.V. DOWNeS

9. John Glassco, "The Opaque Medium », MeTA, XIV, 1 (mars 1969): 27. 